\title{
Slipping Off the Edge: How and why Democratic Regimes Fall into Excess in their Fight against Terrorism
}

\author{
Denis Proshin \\ Dnipropetrovs'k Alfred Nobel University, 18, Naberezhna Lenina Str., Dnipropetrovs'k, 49000, \\ Ukraine \\ denis.v.proshin@gmail.com
}

Keywords: terrorism, democracy, illiberal democracy, counterterrorism, excessive force

\begin{abstract}
Democratic regimes' resorting to excessive force when fighting against terrorists is chrestomathically defined as "deviations" or "mistakes". However, the frequency with which such "deviations" and "mistakes" take place and regular repetition of several scenarios give us the right to speak not so much about random dysfunctions as about standard political situations in whose framework, contrary to assertions of democracies' immanent softness and moderation in administering violence even to their avowed enemies, democratic regimes with high probability can apply excessive force to their armed antagonists. This article wants to probe deeper into the question of the causes of such behaviour of democratic governments and to outline most probable sociopolitical scenarios of these governments' falling into excess while combating terrorists.
\end{abstract}

\section{Introduction}

Researchers who study the problem of the violent response given to terrorist threat by democratic regimes $[1,2,3,4,5]$ traditionally depart from three interrelated premises.

Firstly, democratic regimes by definition are characterized by the supremacy of the law, the independence of the judicial system and the inviolability of human rights and civil liberties.

Democracy gives to those dissatisfied with sociopolitical status quo legal means to express their dissatisfaction and try to peacefully bring about decisions aimed at redressing voiced grievances. Some researchers even argue that there exists a negative correlation between democracy and terrorism. In a nutshell, more democracy means less terror, to rephrase the title of one of numerous studies on the subject [6].

Secondly, peculiarities of their political and legal order make democracies more restrained, compared to dictatorships, in applying force even to avowed political enemies.

Pointing at this, some authors argue that such "softness" could make democracies susceptible to terrorist violence [7]. Democratic regimes do not just deny the police or security forces a free hand; they are said to be too humane, treasuring every human life and therefore providing terrorists with plenty of easy targets. In other words, from this point of view, more democracy means more terrorism. (At least since early 1990s, this "cursed question" of whether democracy decreases or increases terrorism has been one of the main subjects of the discussion on the problem of democracy and terrorism. American researcher Leonard Weinberg, in his above cited book commenting on this debate's interim results and prospects, draws rather pessimistic picture of possible debating the issue "back and forth until ennui or exhaustion sets in" [5].)

Thirdly, even when facts of applying excessive force by democratic regimes are incontrovertible, it is presented as "mistakes" or "deviations" from that moderate line which democracies allegedly intrinsically follow regardless of anything. (By "the application of excessive force", this author means the use of violence whose intensity unquestionably surpasses the level of the existing threat and which is aimed not at the neutralization of the enemy (where it is possible), but at the enemy's destruction and the intimidation of those who are not directly involved into terrorist activity.)

The question of the use of excessive force in countering terrorism is not limited to purely judicial or ethical issues (which alone would have warranted interest in this problem). Counterterrorism experience demonstrates that applying excessive force could not so much eradicate the threat as 
lead to the escalation of a conflict. It could discredit a regime giving additional weight to terrorists' accusations against authorities; or increase the number of a ruling regime's opponents at the expense of those who suffered from authorities' wanton violence or solidarized themselves with the victims of repressions; or finally, increase the cohesion of already existing anti-government organizations and elevate the level of their aggressiveness.

The use of excessive force against terrorists by democratic governments is almost automatically defined as "deviations" or "mistakes". However, the frequency with which such "deviations" and "mistakes" take place, their duration and scale and regular repetition of several scenarios provide ground for talking about standard political situations, not just random dysfunctions, in whose framework, contrary to assertions of democracies' immanent softness and moderation in administering violence even to their avowed enemies, democratic regimes with high probability can apply excessive force to their armed antagonists.

\section{Democracy. Nothing more}

In the first place, it should be noted that the idea of the excessive force being alien to democratic regimes is based on the distorted understanding of democracy which emphasizes only one of democracy's variations - a liberal one with its stably high legal standards and respect of human rights and civil liberties.

However, the democratic character of the political regime manifests itself, sensu stricto, in a limited set of procedures through which particular organs of political authority are formed and empowered and certain political decisions are made. The notions of "the will of the majority", "voting," "people's representation" are not put squarely into any clearly defined political or ethical coordinate system and merely refer to certain procedures that, however important they may be, do not define the whole complex of sociopolitical relations. To put it in another way, a democratic decision could be not only "technically" wrong, but also unjust. Fulfilment of the majority's will could mean the utter neglect of interests of the minority. Finally, the very nature of the dominant majority could be unjustly artificial (due to various forms of gerrymandering, discrimination, etc.).

In other words, the democraticality of a regime is basically a formal characteristic not necessarily implying the presence of a number of other significant sociopolitical features which, however, are virtually automatically attributed to democracy when liberal democracy is being presented as "democracy as such".

In his classic research devoted to the "waves" of democratization, Samuel Huntington notes: "Governments produced by elections may be inefficient, corrupt, shortsighted, irresponsible, dominated by special interests, and incapable of adopting policies demanded by the public good. These qualities may make such governments undesirable but they do not make them undemocratic" [8] (italics added).

In this light, one should speak of the gradation of democratic regimes which demonstrate different levels of stability of political institutions, legal system and respect for the rights of various minorities. The bottom threshold of this gradation form those regimes which Fareed Zakaria defines as "illiberal democracies" [9]. These illiberal democratic regimes possess minimal attributes of democracy (a multi-party system, holding of relatively free elections, an existence of at least marginally free mass media). At the same time, they are characterized by the unwarranted expansion of the executive branch's authority at the expense of the legislative and judicial branches; by the rise of strong leaders who, after being elected, try to "fulfill the people's will" circumventing legal "formalities"; by the aggressiveness of leading political parties to minorities which are pushed to the political periphery not only "in the name of the people", but quite often with real and substantial popular support.

In those cases when the problem of terrorism is dealt with by illiberal democratic regimes, authorities unhesitatingly and systematically cross the limit of sufficient force both with regard to terrorists and those who suspected of supporting them (Sri Lanka, 1980s-2000s; Peru, 1990s). It should be added that the application of excessive force to terrorists and their real (or alleged) sympathizers could be the sign of the accelerating degradation of illiberal democracy consequently 
leading to its transformation into an openly authoritarian regime (Uruguay, 1973; Argentina, 1976) ${ }^{1}$. However, the possibility of the latter scenario does not eliminate the specifics of the counterterrorism practice of illiberal democracies and this practice's combination with purely democratic procedures.

For example, in 1992, Peru's President Alberto Fujimori staged an autogolpe (a self-coup), dissolved the Parliament and sharply expanded Presidential powers not in the last place justifying his actions by pointing at the necessity to respond to the terrorist threat $[12,13]$. But, contrary to the cases with Uruguay and Argentina where activities of political parties were strictly curtailed or prohibited and elections banned, the Peruvian illiberal democratic scenario was realized with the broad use of democratic mechanisms. It is worth noting that in the 1995 Presidential elections Fujimori's actions (including the complex of harsh counterterrorism measures he had introduced) received genuine and substantial support from voters (the incumbent president was reelected by a majority of $64 \%$ of voters collecting more votes than all other 13 candidates combined and thrice as many votes as his nearest competitor, former U.N. Secretary General Javier Perez de Cuellar) [14].

In their counterterrorism practice, illiberal democracies with easiness cross the threshold of sufficient force. However, the issue of democratic governments using excessive force against their armed opponents is not limited to illiberal democracy or, more broadly, - is not tantamount to the question of the relative perfection of the democratic political order. The remaining part of this article is devoted to the factors which are able - regardless of how fully a given regime incarnates the principles of democracy - to push a government towards actions leading to the use of excessive force or already constituting such use.

\section{Democracy vs. terrorism: scenarios and traps}

Firstly, the probability of a democratic government applying excessive force to its armed opponents increases proportionally to the scope of the conflict with which this government is dealing. In the first place, it can be observed in the choice of those who will be charged with terrorism counteraction. Facing a large-scale confrontation, a government could come to believe that the only effective way to solve the problem is to use against terrorists not the police (or analogous law enforcement agencies), but the regular military forces. Such decision could be understood by a government as serving the public interest. Nevertheless, the very nature of the military forces - the way in which they are trained, their tasks and methods - carries with itself the danger of the further escalation of a conflict.

Contrary to the police and other law enforcement bodies which are focused at the neutralization and apprehension of criminals for them being next handed over to investigative and judicial authorities, the military forces as an instrument of war are by definition oriented at the destruction of an enemy or at least at the infliction upon an enemy of the maximum possible (physical or psychological) damage [15]. Even in the cases when the military forces are involved in counterterrorism activities only as one of the actors and are charged only with the most challenging tasks (for example, patrolling those areas which are too dangerous for lightly armed police officers), the very presence of the armed forces inevitably and tangibly raises the risk of the military units administering force that is excessive in the context of counterterrorism measures. It is especially so if and when the military conduct their duties in close contact with a civilian population (e.g. the events of "Bloody Sunday" in Londonderry, 30 January $1972^{2}$ ). Applying excessive force may not

\footnotetext{
${ }^{1}$ One of the Argentinean army commanders notoriously commented on the junta's intentions regarding the antigovernment armed underground: "We are going to kill 50,000 people; 25,000 subversives, 20,000 sympathizers, and we will make 5,000 mistakes" (quoted in: [10]). The final death toll of the Junta Militar which ruled Argentina in 19761983 is lower than these "projected figures", yet nevertheless it is chillingly high (between 10,000 and 30,000 people were killed during the so-called Guerra Sucia (the "Dirty War") [11]).

2 "Bloody Sunday" refers to the incident that took place in Londonderry when British paratroopers while dispersing a peaceful demonstration opened fire on unarmed protesters killing 13 people on the spot (the $14^{\text {th }}$ victim died some 4 months later) and injuring 14 more.
} 
count among intentions of a government which decided to use the military against terrorists. Nevertheless, it does not mean that this government can consider itself free from any responsibility for potential (and highly probable) consequences of its decision.

Secondly, the chances that a democratic government will use excessive force against its antagonists are higher if a conflict separates two distinctively specific social groups with a government being closely related to one of them, formed for the most part or exclusively of this group's representatives and accountable primarily to this group (the protracted and bloody conflict between the Singhalese majority and the Tamil minority in Sri Lanka, 1983-2009, can represent here the case in point) $[16,17]^{3}$. Under such conditions, political pressure from its "own" social group may goad a government towards using extremely harsh or excessive measures in order to protect interests its "own" constituency against terrorist threat from the "others".

The larger is the social, cultural and sometimes even spatial distance between opposing groups, the higher is the probability of excessive force being applied, which was (or is) regularly observed during the conflicts taking place in the territories occupied by democratic countries or representing the "relics" of those countries' imperial past (for instance, the Israeli-Palestinian conflict; the war of independence in Algeria, 1950s-1960s). It also needs to be underlined that the escalation of governmental violence could represent not only a reaction to the threat from the "others", but also in case when a government comes under criticism from hawkish elements within its "own" constituency - could be intended to neutralize these elements' influence and help a government survive the struggle against its political competitors. For example, one could turn to highly controversial measures (operation Demetrius) for mass internment of those suspected of being members or sympathizers of the Irish Republican Army which were undertaken by the government of Northern Ireland in 1971 not in the last place with the aim of neutralizing its vocal opponents from the radical Protestant Unionist circles $[19]^{4}$.

Thirdly, the probability of a democratic government applying excessive force to its violent antagonists also increases in cases when terrorist organizations fighting against this government succeed in dealing a major blow to the state. In such situations, a government's restrain in applying force against terrorists may be perceived not only by the armed opposition, but also by this government's own constituents as the sign of weakness and inability to protect national security. This public mood could, on the one hand, demand that a government act decisively, and, on the other hand, provide carte blanche for a government to conduct particularly harsh responsive actions avoiding possible limitations, paving the way to the imposition of dubious legal norms, etc.

Moreover, in those flagrant cases when a crisis created by a resonant terrorist attack is aggravated by pogroms and outbursts of mob justice aimed against the social group in which interests terrorists pretend to act, a government could limit itself to ostentatious half-measures to restore order not wanting to risk its reputation in the eyes of enraged potential voters who took to streets (for example, anti-Sikh pogroms in India after the assassination of Prime Minister Indira Gandhi by two her Sikh bodyguards in $1984^{5}$ ).

\footnotetext{
${ }^{3}$ Two main Sri Lankan (Singhalese) political parties - Freedom Party (FP) and United National Party (UNP) - for decades have engaged one another in what Neil De Votta called "ethnic outbidding" - in other words, the exploiting of nationalist sentiments of the large numbers of Singhalese voters [18]. Initially, UNP championed greater equality of the Singhalese majority and the Tamil minority. But after the decisive 1956 election victory which FP achieved from the nationalist, openly anti-Tamil positions (first of all, with regard to the issue of the Sinhala as the only official language), the UNP leadership recognized the inadequacy of its agenda to the expectations of Singhalese voters and revised its political course.

${ }^{4} 342$ people were arrested on 9-10 August 1971. In total, 2,060 suspected Irish republicans were interned without trial between 1971 and 1975 [20] only few of them actually being involved into any illegal activity. It is a telling detail that first loyalists were interned no sooner than February 1973 [21].

${ }^{5}$ According to the report of Commission of Inquiry into the circumstances of the 1984 anti-Sikh riots, 2,800 people were killed throughout India in 4 days, from 31 October to 3 November 1984 (2,100 deaths in New Delhi alone) [22].
} 


\section{Conclusion}

What is presented in this article should be viewed as a cautious preliminary outline of the problem which prepares the ground for further analysis. However, even at this early stage one can easily observe that the issues of the nature of democracy, democratic regimes combating terrorism and the controversial character of this combat require an unbiased approach free of idealizing democracy and the like distortions.

Avoiding as much as possible the repetition of the already presented findings (on illiberal democracies' easily turning to excessive force or risks awaiting all democratic regimes fighting terrorism), this author in conclusion wants to return only to one issue. As previously mentioned, since no later than early $1990 \mathrm{~s}$, the question of whether more democracy means more or less terrorism has been exercising researchers' minds. In what sometimes looks like the recent edition of a scholastic debate, democracy is being presented as either a "soft target" for terrorist attacks or the "good genius" (to borrow the phrase from the Bush Administration's 2006 National Security Strategy [23]) capable of alleviating social grievances, decreasing the level of political violence or even extinguishing political conflicts (and, consequently, terrorism) altogether. However, from the point of view presented in this article it is clear that democracy could also be neither "soft", nor healing. It should be kept in mind in any further discussion of democracy and terrorism that nothing in the nature of democracy (if it is not viewed through the rose-coloured glasses) necessarily makes it timid, lenient or weak. Nothing automatically makes any formally democratic regime just, either.

"Slipping of the edge" in the use of force against terrorists should be treated as reflecting - under certain circumstances - the nature of democracy. And this excessively violent variation of democracy needs to be taken into consideration if we are to better understand how democratic regimes may proceed in their dealing with terrorist threat, and why. This understanding may be required not only to help protect democracy from terrorism, but also protect democracy from its own violent counterterrorism reactions.

\section{References}

[1] Information on http:// http://www.digitalcommons.mcmaster.ca/opendissertations/6417

[2] W. Laqueur, A History of Terrorism, Transaction Publishers, 2002.

[3] T. Parker, Fighting an Antaean Enemy: How Democratic States Unintentionally Sustain Terrorist Movements They Oppose, Terrorism and Political Violence. 19 (2007) 155-179.

[4] A. Silke, Fire of Iolaus: the role of state countermeasures in causing terrorism and what needs to be done, in: T. Bjørgo (Ed.), Root Causes of Terrorism: Myths, Reality and Ways Forward, Routledge, Abingdon, 2005, pp. 241-255.

[5] L. Weinberg, Democracy and Terrorism: Friend of Foe? Routledge, Abingdon, 2013.

[6] D. Dassa Kaye et. al., More Freedom, Less Terror: Liberalization and Political Violence in the Arab World, RAND Corporation, 2008.

[7] A. Schmid, Terrorism and Democracy, in: R. Crelinsten, A. Schmid (Eds.), Western Responses to Terrorism, Frank Cass Publishers, London, 2004.

[8] S. Huntington, The Third Wave: Democratization in the Late $20^{\text {th }}$ Century, University of Oklahoma Press, 1991.

[9] F. Zakaria, The Rise of Illiberal Democracy, Foreign Affairs. 6 (1997) 22-43.

[10] L. Tedesco, Democracy in Argentina: Hope and Illusion, Routledge, 1999.

[11] L. Richardson, What Terrorists Want: Understanding the Enemy, Containing the Threat, Random House, 2006.

[12] Information on http:// http://www.csmonitor.com/1992/0519/19051.html

[13] C. Valdez, Fujimori begins new anti-terror crackdown, Executive Intelligence Review. 20 (1992) 45.

[14] F. Tuesta Soldevilla, Peru, in: D. Nohlen (Ed.), Elections in the Americas: A Data Handbook. Volume 2: South America, Oxford University Press, Oxford, 2005, pp. 445-486. 
[15] G. Hughes, The Military's Role in Counterterrorism: Examples and Implications for Liberal Democracies, Strategic Studies Institute, 2011.

[16] Information on http:// http://foreignpolicy.com/2014/05/19/five-years-after-illiberaldemocracy-and-potemkin-peace-in-sri-lanka/?wp_login_redirect $=0$

[17] T. Marks, Sri Lanka and the Liberation Tigers of Tamil Eelam, in: R. Art, L. Richardson (Eds.), Democracy and Counterterrorism: Lessons from the Past, United States Institute of Peace, Washington, 2007, pp. 483-530.

[18] N. De Votta, The Liberation Tigers of Tamil Eelam and the Lost Quest for Separatism in Sri Lanka, Asian Survey. 6 (2009) 1021-1051.

[19] M. McCleery, Debunking the Myths of Operation Demetrius: The Introduction of Internment in Northern Ireland, Irish Political Studies. 1 (2012) 1-20.

[20] ---, Operation Demetrius and its aftermath: A new history of the use of internment without trial in Northern Ireland 1971-1975, Manchester University Press, 2015.

[21] Information on: http:// http://cain.ulst.ac.uk/events/intern/sum.htm

[22] Justice Nanavati Commission of Inquiry (1984 Anti-Sikh Riots), Report, Volume-I (2000).

[23] The National Security Strategy of the United States of America, Washington, DC (2006). 